\title{
Study of Ki-67 Immunostaining in Breast Carcinoma and it's Correlation with Grade of Tumor and Lymph Node
}

\author{
Mahendra Singh $^{1}$, Swetlana Sachan ${ }^{2 *}$, Neelima Verma ${ }^{3}$, Anita Omhare ${ }^{4}$, Anveksha Sachan ${ }^{5}$ \\ ${ }^{1}$ Professor and Head, Department of Pathology, G.S.V.M. Medical College, Kanpur, U.P, India \\ 2,5Junior Resident III, Department of Pathology, G.S.V.M. Medical College, Kanpur, U.P, India \\ ${ }^{3}$ Associate Professor, Department of Pathology, G.S.V.M. Medical College, Kanpur, U.P, India \\ ${ }^{4}$ Assistant Professor, Department of Pathology, G.S.V.M. Medical College, Kanpur, U.P, India
}

\begin{abstract}
*Address for Correspondence: Dr. Swetlana Sachan, Junior Resident III, Department of Pathology, G. S. V. M. Medical College, Kanpur, India

E-mail: swetlana.sachan@gmail.com
\end{abstract}

Received: 12 Aug 2018/ Revised: 17 Oct 2019/ Accepted: 26 Nov 2019

\begin{abstract}
Background: Breast cancer is the commonest cancer in women worldwide and represents a disease with wide spectrum particularly in terms of tumour histology, biology, prognosis and response to therapy. Breast cancer is characterized by cellular heterogeneity.

Methods: The study was conducted in the Department of Pathology, GSVM Medical College, Kanpur and associated hospital of Kanpur from January 2018 to September 2019 on patients of breast carcinoma. These cases were selected from the outpatient and inpatient of LLR Hospital, Kanpur, India. In the present study, we had taken a total of 80 cases of invasive breast carcinoma as well as Histomorphology, Ki-67 immunostaining and it's a correlation with lymph node status and tumour grade were studied.

Results: This study leads us to conclude that the peak incidence of invasive breast carcinoma was reported in the age group of 41 to 50 years (with mean age 47.32 year and the standard deviation was 11.63 ). In the present study, the most common histological type was invasive ductal carcinoma, not otherwise specified (NOS). In our study, $66.25 \%$ of cases had metastatic lymph nodes and half of them were having more than 4 metastatic lymph node.

In the grade-II of Bloom Richardson Grading system, there were $40 \%$ cases and in grade-III there were $35 \%$ of cases and grade-I has shown $25 \%$ of cases. A significant association was found between the grade of the tumor and the lymph node positivity.

Conclusion: The present study concluded a positive correlation between the grade of tumour and Ki-67 immunohistochemistry, which was used as a prognostic and predictive parameter.
\end{abstract}

Key-words: Bloom Richardson's grading, Breast carcinoma, Histomorphology, Immunostaining, Invasive ductal carcinoma, Ki-67

\section{INTRODUCTION}

Breast cancer is known to be a heterogeneous disease. In addition to the conventional histopathological parameters, the assessment of proliferation is one of the major factors for the treatment decisions in breast cancer patients ${ }^{[1]}$. The incidence of breast cancer is low in India but rising. Breast cancer is the commonest cancer of urban Indian women and the second commonest in rural women.

\section{How to cite this article}

Singh M, Sachan S, Verma N, Omhare A, Sachan A. Study of Ki-67 Immunostaining in Breast Carcinoma and it's Correlation with Grade of Tumor and Lymph Node. SSR Inst. Int. J. Life Sci., 2019; 5(6): 2421-2427.

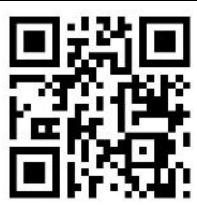

Access this article online https://iijls.com/
Owing to the lack of awareness of this disease and in the absence of a breast cancer screening program, the majority of breast cancers are diagnosed at a relatively advanced stage. The quality of care available for breast cancer patients varies widely according to where the patient is treated ${ }^{[2]}$.

Premalignant breast lesions are relatively common but only a small proportion appear to progress to invasive breast cancer. Most breast cancer occurs in women and the number of cases is 100 times higher in women than that in men. Breast cancer can commonly metastasize to distant organs such as the bone, liver, lung and brain. The widely used screening method is mammography for the detection of breast cancer and it reduces the mortality effectively ${ }^{[3]}$.

The mortality rate of breast cancer decreases due to the 
widespread early screenings and advanced medical therapies. Recently biological therapies have been proved to be beneficial for breast cancer ${ }^{[4]}$. Ki-67 antibody reacts with a nuclear non-histone protein present in all active phases of the cell cycle except the G0 phase ${ }^{[5]}$. Ki-67 is used as a marker of cell proliferation and used to stratify patients into good and poor prognostic categories ${ }^{[6]}$. Those tumors, which are Ki-67 positive, are more active in growth, more aggressive in the invasion, and more metastatic ${ }^{[7]}$.

\section{MATERIALS AND METHODS}

This study was done in the Department of Pathology, G.S.V.M. Medical College Kanpur, India from January 2018 to August 2019. Total of 80 female patients were included in the study. We included in our study histomorphology and lymph node status in breast carcinomas, and $\mathrm{Ki}-67$ immunostaining in all these breast carcinomas and its prognostic importance. Tumor mass was subjected to Immunohistochemistry (IHC). The above study was approved by the Ethical Committee and informed consent was obtained from the patients before the study. The modified Bloom-Richardson Histopathological grading ${ }^{[8]}$ was used in this present study.

\section{Inclusion criteria}

1. Mastectomy specimens of clinically/cytologically diagnosed breast malignancy in the female of all age group

2. Patients, who gave written informed consent

\section{Exclusion criteria}

1. Patients with metastatic malignancy of the breast

2. Patients already treated for contra-lateral breast cancer

\section{RESULTS}

Table 1 shows that a total of 80 cases of infiltrating breast carcinoma were analyzed in this study and $47.50 \%$ cases belonged to the age group of 41 to 50 years and after that $17.5 \%$ cases belonged to 51 to 60 years and also in 61 to 70 years. Mean age was 47.32 and the standard deviation was 11.63 .
Table 1: Distribution of cases based on age group

\begin{tabular}{cccc}
\hline $\begin{array}{c}\text { S. } \\
\text { No. }\end{array}$ & Age group & $\begin{array}{c}\text { No. of cases } \\
(\mathbf{n}=\mathbf{8 0})\end{array}$ & Percentage (\%) \\
\hline 1 & $0-30$ yrs & 03 & 3.75 \\
2 & $31-40$ yrs & 10 & 12.5 \\
3 & $41-50$ yrs & 38 & 47.5 \\
4 & $51-60$ yrs & 14 & 17.5 \\
5 & $61-70$ yrs & 14 & 17.5 \\
6 & $>70$ yrs & 01 & 1.25 \\
\hline
\end{tabular}

Table 2 shows that $60(78 \%)$ cases were diagnosed as invasive ductal carcinoma, 4 cases (5\%) of invasive lobular carcinoma, and 2 cases $(2.50 \%)$ of invasive papillary carcinoma. Total 7 cases $(8.75 \%)$ of medullary carcinoma, 5 cases $(6.25 \%)$ of mucinous carcinoma and 2 cases $(2.50 \%)$ of tubular carcinoma were found in our study.

Table 2: Distribution of cases based on histological types

\begin{tabular}{rccc}
\hline S. No. & Histological types & $\begin{array}{c}\text { No. of cases } \\
(\mathbf{n}=\mathbf{8 0})\end{array}$ & $\begin{array}{c}\text { Percentage } \\
\text { (\%) }\end{array}$ \\
\hline 1. & $\begin{array}{c}\text { Invasive ductal } \\
\text { carcinoma }\end{array}$ & 60 & 78 \\
2. & $\begin{array}{c}\text { Invasive lobular } \\
\text { carcinoma }\end{array}$ & 04 & 05 \\
3. $\quad \begin{array}{c}\text { Invasive papillary } \\
\text { carcinoma }\end{array}$ & 02 & 2.50 \\
4. & $\begin{array}{c}\text { Medullary } \\
\text { carcinoma }\end{array}$ & 07 & 8.75 \\
5. & $\begin{array}{c}\text { Mucinous } \\
\text { carcinoma }\end{array}$ & 05 & 6.25 \\
6. & Tubular carcinoma & 02 & 2.50 \\
\hline
\end{tabular}

Table 3 shows that in Bloom Richardson grading, 40\% of cancer belongs to grade II. Total $35 \%$ of cases belong to grade III and $25 \%$ of cases belong to grade I.

Table 3: Distribution of cases based on histological grades (Bloom Richardson grade)

\begin{tabular}{cccc}
\hline S. No. & $\begin{array}{c}\text { Histological } \\
\text { Grades }\end{array}$ & $\begin{array}{c}\text { No. of } \\
\text { cases } \\
(\mathbf{n = 8 0})\end{array}$ & $\begin{array}{c}\text { Percentage } \\
\text { (\%) }\end{array}$ \\
\hline 1 & BRG-I & 20 & 25 \\
2 & BRG-II & 32 & 40 \\
3 & BRG-III & 28 & 35 \\
\hline
\end{tabular}

BRG= Bloom Richardson grade 
Table 4 shows that Tumor size had 2 to $5 \mathrm{~cm}$ in 49 cases (61.25\%) had tumor size between 2 to $5 \mathrm{~cm}, 22$ cases (27.50\%) had tumor size more than $5 \mathrm{~cm}$ and 9 cases (11.25\%) had tumor size between 1 to $2 \mathrm{~cm}$.

Table 4: Distribution of cases based on tumor size

\begin{tabular}{cccc}
\hline $\begin{array}{c}\text { S. } \\
\text { No. }\end{array}$ & $\begin{array}{c}\text { Tumor size } \\
(\mathbf{c m})\end{array}$ & $\begin{array}{c}\text { No. of cases } \\
(\mathbf{n}=\mathbf{8 0})\end{array}$ & $\begin{array}{c}\text { Percentage } \\
\mathbf{( \% )}\end{array}$ \\
\hline 1 & $<2$ & 09 & 11.25 \\
2 & $2-5$ & 49 & 61.25 \\
3 & $>5$ & 22 & 27.50 \\
\hline
\end{tabular}

In Table 5, out of 80 cases of invasive breast carcinoma, a total of 53 cases [ 27 positive (1-3 nodes) and 26 positives (4 or more )] were lymph node-positive found in our study.

Table 5: Distribution of cases based on lymph node status

\begin{tabular}{cccc}
\hline $\begin{array}{c}\text { S. } \\
\text { No. }\end{array}$ & $\begin{array}{c}\text { Lymph node } \\
\text { status }\end{array}$ & $\begin{array}{c}\text { No. of } \\
\text { cases } \\
(\mathbf{n = 8 0})\end{array}$ & $\begin{array}{c}\text { Percentage } \\
\mathbf{( \% )}\end{array}$ \\
\hline 1 & Not identified & 17 & 22.97 \\
2 & Negative (0 node) & 10 & 13.51 \\
3 & $\begin{array}{c}\text { Positive (1-3 } \\
\text { nodes) }\end{array}$ & 27 & 32.43 \\
4 & $\begin{array}{c}\text { Positive (4 or } \\
\text { more ) }\end{array}$ & 26 & 31.08 \\
\hline
\end{tabular}

In Table 6, total of 17 cases showed low Ki-67 immunostaining, 25 cases show high Ki-67 immunostaining whereas, 38 cases show very high Ki-67 immunostaining.

Table 6: Distribution of cases based on Ki-67 immunostaining

\begin{tabular}{cccc}
\hline $\begin{array}{c}\text { S. } \\
\text { No. }\end{array}$ & $\begin{array}{c}\text { Ki-67 } \\
\text { immunostaining }\end{array}$ & $\begin{array}{c}\text { No. of } \\
\text { cases } \\
(\mathbf{n}=\mathbf{8 0})\end{array}$ & $\begin{array}{c}\text { Percentage } \\
\mathbf{( \% )}\end{array}$ \\
\hline 1 & Low (<10\%) & 17 & 21.75 \\
2 & High (10-15\%) & 25 & 31.25 \\
3 & Very high (>15\%) & 38 & 47.50 \\
\hline
\end{tabular}

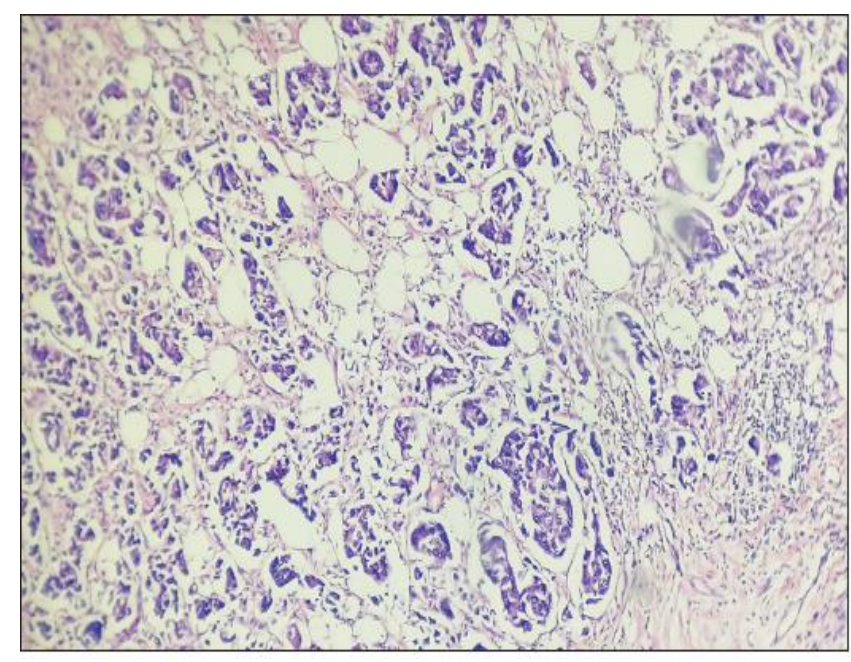

\section{A. (H\&E, 10x)}

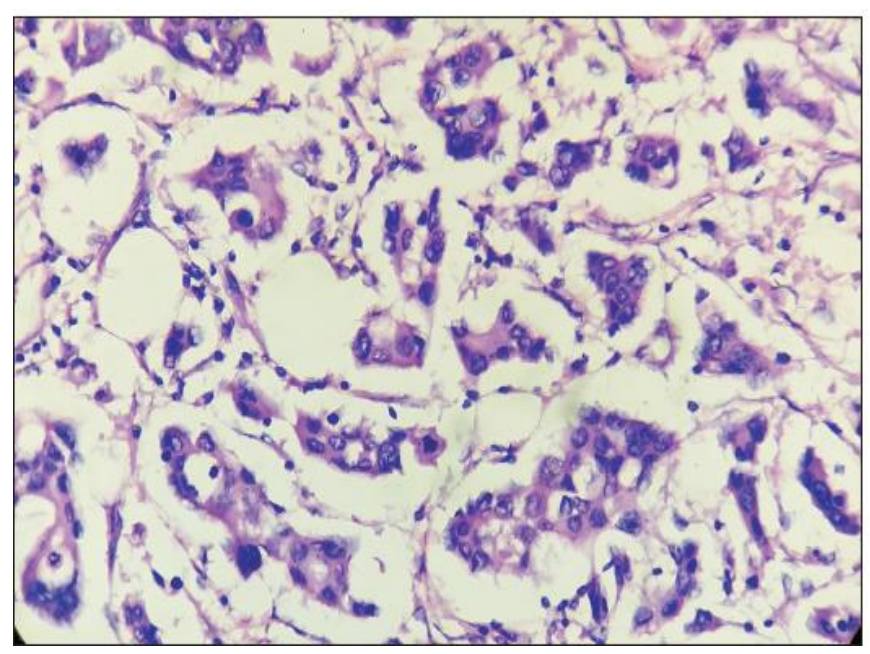

B. $(H \& E, 40 x)$

Fig. 1 (A \& B): Infiltrating ductal carcinoma, grade-1

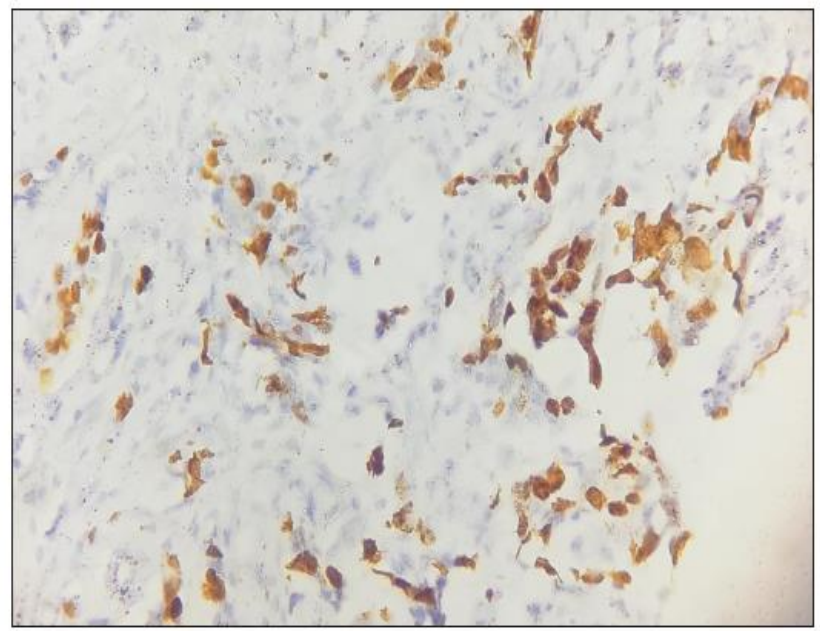

Fig. 2: Infiltrating ductal carcinoma, grade-1 [Immunohistochemical staining of Ki-67 positivity showing low (<10\%) proliferative activity (40x)] 


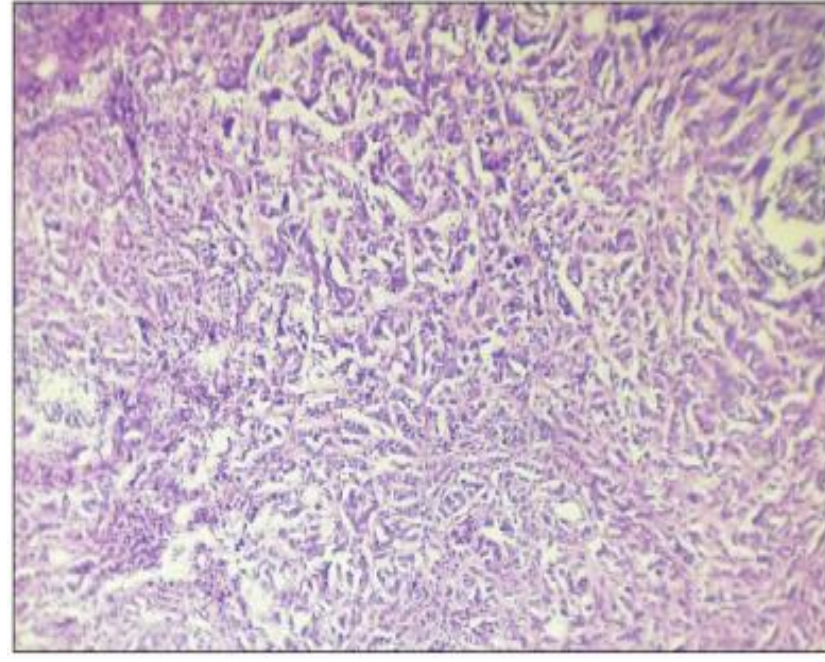

A. $(H \& E, 10 x)$

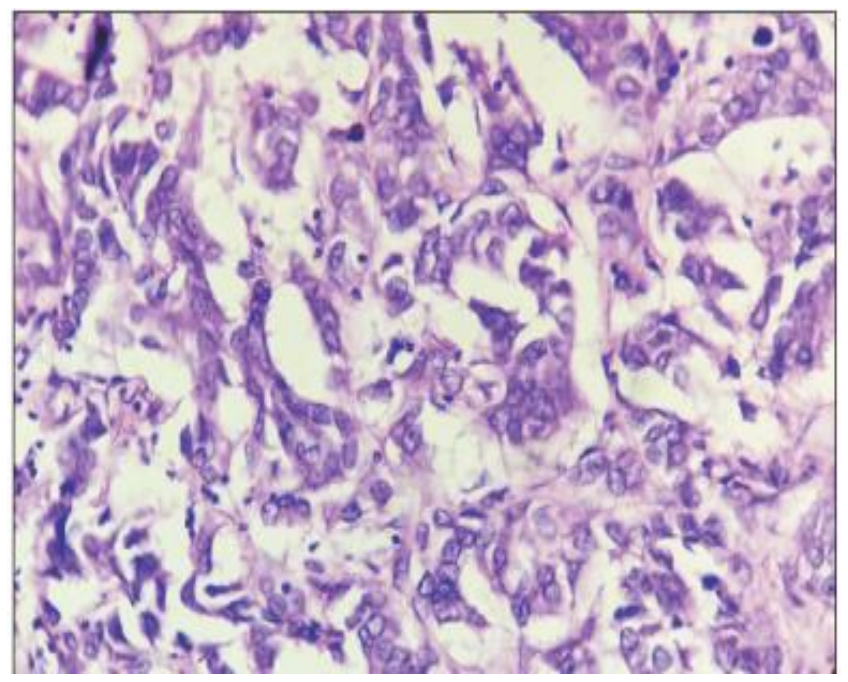

B. $(H \& E, 40 x)$

Fig. 3: (A\&B): Infiltrating ductal carcinoma (NOS), Grade 2

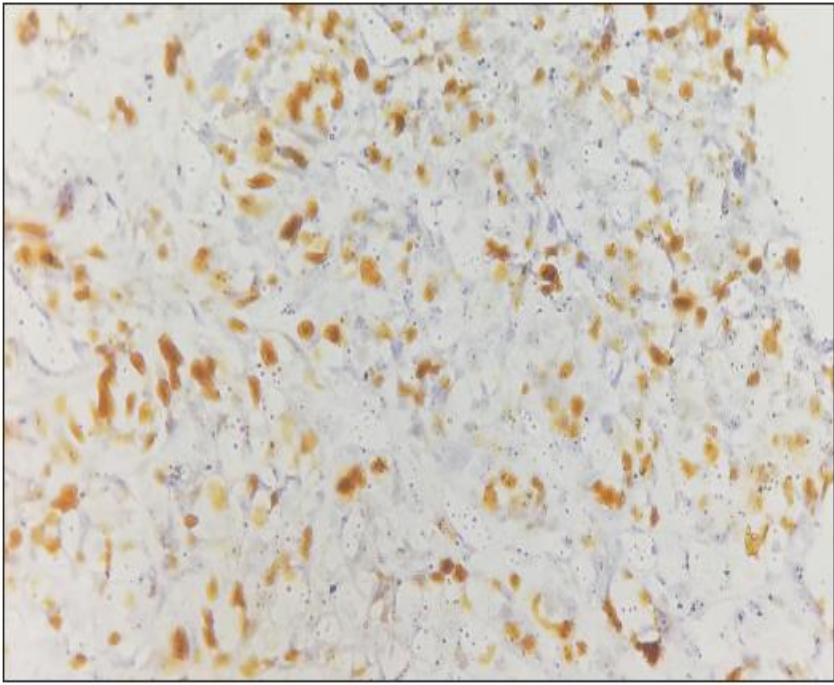

Fig 4: Infiltrating ductal carcinoma, grade-2 [Immunohistochemical staining of Ki-67 showing high (10-15\%) proliferative activity (40x)]

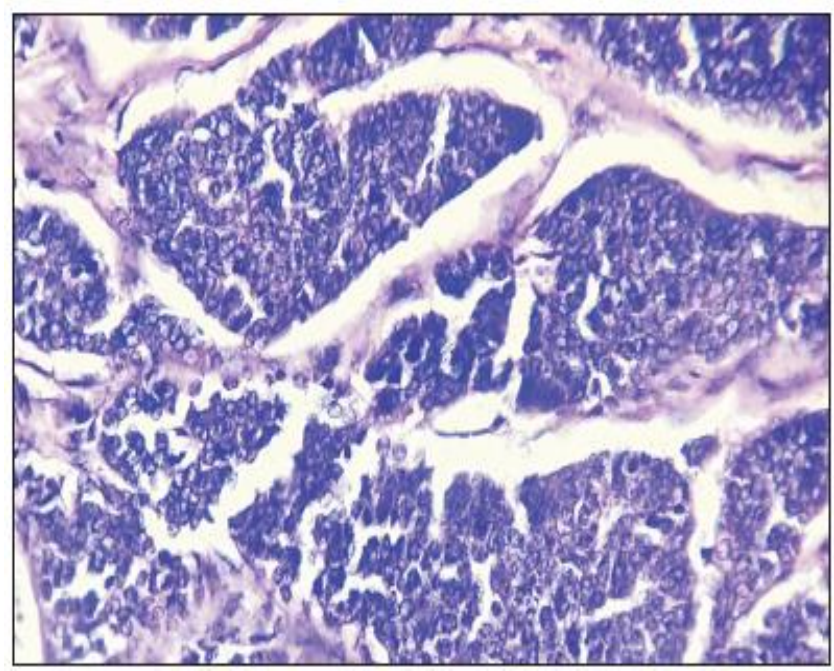

Fig 5: Infiltrating ductal carcinoma (NOS), grade-3 (H\&E, 40x)

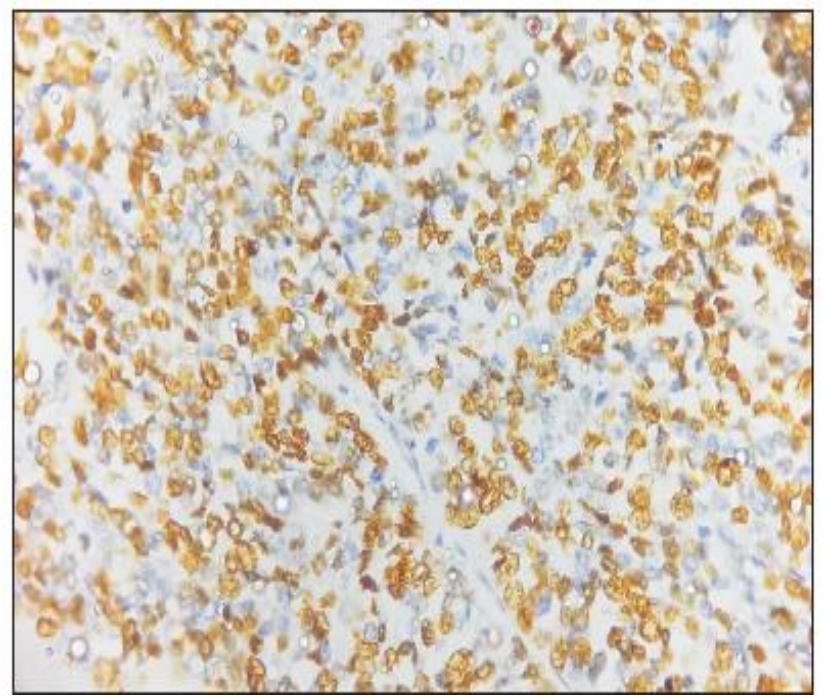

Fig 6: Infiltrating ductal carcinoma (NOS), grade-3 (40x) [Immunohistochemical staining of Ki-67 showing very high (>15\%) proliferative activity]

In Table 7, in grade I, out of 20 cases, maximum 9 numbers of cases had low Ki-67 immunostaining, 8 cases had high and 3 cases had very high Ki-67 immunostaining. In grade II, out of 32 cases, maximum 15 numbers of cases showed very high, 13 cases had high Ki-67 immunostaining and 4 cases shown low Ki-67 immunostaining. In grade III, out of 28 cases, maximum 20 number of cases shown very high Ki-67 immunostaining and 4 cases belonged to each low and high Ki-67 immunostaining. 
Table 7: Correlation between grade of tumor and Ki-67 immunostaining

\begin{tabular}{cccccc}
\hline $\begin{array}{c}\text { Grade } \\
\text { of } \\
\text { tumor }\end{array}$ & $\begin{array}{c}\text { No. of cases } \\
(\mathrm{n}=\mathbf{8 0})\end{array}$ & $\begin{array}{c}\text { No. of low Ki-67 } \\
\text { immunostaining } \\
\text { cases } \\
(\mathrm{n}=\mathbf{1 7})\end{array}$ & $\begin{array}{c}\text { No. of high } \\
\text { Ki-67 } \\
\text { immunostaining } \\
\text { cases }(\mathrm{n}=\mathbf{2 5})\end{array}$ & $\begin{array}{c}\text { No. of very high } \\
\text { Ki-67 } \\
\text { immunostaining } \\
\text { cases }(\mathrm{n}=\mathbf{3 8})\end{array}$ & Significance \\
\hline I & 20 & 09 & 08 & 03 & Chi square $\left(\mathrm{X}^{2}\right)=$ \\
II & 32 & 04 & 13 & 15 & 18.89 \\
III & 28 & 04 & 04 & 20 & p value $=0.008$ \\
\hline
\end{tabular}

Chi-square statistics was used and the value of chisquare was 18.89 and the p-value was 0.008 . It showed that there was a significant association between the grade of tumor and Ki-67 immunostaining.

In Table 8, total 53 of cases were lymph-node positive in our study and out of total 53 cases, 9 cases shown low Ki-67 immunostaining, 16 cases shown high Ki-67 immunostaining and 28 cases showed very high Ki-67 immunostaining.

The Chi-square statistics was applied and it shows the value of chi square was 9.48 and the $p$-value was less than 0.05 so there was a significant association between Ki-67 immunostaining and lymph-node positivity.

Table 8: Correlation between Ki-67 immunostaining and lymph node positive cases

\begin{tabular}{|c|c|c|c|c|}
\hline Ki-67 immunostaining & $\begin{array}{c}\text { Low } \\
(<10 \%)\end{array}$ & $\begin{array}{c}\text { High } \\
(10-15 \%)\end{array}$ & $\begin{array}{c}\text { Very High } \\
(>15 \%)\end{array}$ & Significance \\
\hline $\begin{array}{l}\text { No. of lymph node } \\
\text { positive cases } \\
\text { (total } 53 \text { cases) }\end{array}$ & 09 & 16 & 28 & $\begin{array}{c}\text { Chi square }\left(\mathrm{X}^{2}\right) \\
=9.48 \\
\mathrm{p} \text { value less than } \\
0.05\end{array}$ \\
\hline
\end{tabular}

\section{DISCUSSION}

This study shows that peak incidence of breast cancer was in the $5^{\text {th }}$ decade, followed by $6^{\text {th }}$ decade and $7^{\text {th }}$ decade, which was similar to previous, studies i.e. Tiwari et al. ${ }^{[9]}$; Nabi et al. ${ }^{[10]}$; and Nggada et al. ${ }^{[11]}$. All of the cases were females, no male case identified, which was similar with another previous study that done by Shet et al. ${ }^{[12]}$; Godwin et al. ${ }^{[13]}$; and Yip ${ }^{[14]}$. In this study, out of the total 80 cases, 25 were pre-menopausal and rest 55(68.75\%) were postmenopausal; this result was similar with other previous studies Surakasula et al. ${ }^{[15]}$; Sebastiani et al. ${ }^{[16]}$; and Hall et al. ${ }^{[17]}$. In this study, the most common histological type was invasive ductal carcinoma (NOS) comprised of $75 \%$ of total cases. Out of the total $80 \%$ cases, $40 \%$ of cases belonged to grade II of Bloom Richardson grading, while $35 \%$ and $25 \%$ of cases were under grade III and grade I, respectively. This result was similar to other previous studies done by Ayad et al. ${ }^{[18]}$; Soliman et al. ${ }^{[19]}$; Rakha et al. ${ }^{[20]}$; Pierga et al. ${ }^{[21]}$; and Aman et al. ${ }^{[22]}$. In our study, 49 (61.25\%) cases have tumor-size 2 to $5 \mathrm{~cm}, 22(27.50 \%)$ cases have tumor, size $>5 \mathrm{~cm}, 9(11.25 \%)$ cases have tumor-size less than $2 \mathrm{~cm}$. Another study also recorded similarly with our study with the majority of patients presenting with tumor-size of 2 to $5 \mathrm{~cm}$ by Pinto et al. ${ }^{[23]}$; Cheang et al. ${ }^{[24]}$.

In our study, $66.25 \%$ of cases have metastatic lymph nodes and half of them are having more than 4 metastatic lymph node, similar studies were observed in the previously published other studies ${ }^{[9,25]}$.

In our study, Grade- 1 consists of total 20 cases out of which the maximum number of cases [9 cases, (45\%)] belonged to low Ki-67 immunostaining. Grade-2 comprises of total 32 cases out of which majority of cases had high and very high Ki-67 immunostaining and Grade3 consists of 28 cases, out of which, maximum cases [20 cases, (71.4\%)] had very high Ki-67 immunostaining. There was a significant association between the grade of 
tumor and Ki-67 immunostaining (P-value <0.05). Our study was shown that the incidence of lymph node metastasis was higher in high Ki-67 positive groups than low Ki-67 positive groups. Other studies also recorded similar findings by Ragab et al. ${ }^{[26]}$; Madani et al. ${ }^{\text {[27]; and }}$ Jain et al. ${ }^{[28]}$.

\section{CONCLUSIONS}

Initially, breast cancer was considered as a single disease; but recent advances in gene expression and genomic profiling have revealed that breast cancer is a collection of diseases expressing distinct anatomical features, responses to treatment and survival. Ki-67 protein is a marker for proliferation. This nuclear protein is expressed in proliferating cells during $\mathrm{G} 1$ through $\mathrm{M}$ phase but is not detected in resting cells. The Ki-67 immunoreactivity detected by immunohistochemistry was the most reliable indicators of the proliferative activity of cancer cells. It was considered as a biomarker for prognosis and sensitivity of cancer cells to endocrine therapy or chemotherapy.

Breast cancer patients will also be treated by focusing on specific oncogenic pathways, which are activated in a particular tumor rather than the location of the tumor or histological type.

\section{ACKNOWLEDGMENTS}

All authors are very thankful to the Department of Pathology, G. S. V. M. Medical College Kanpur, India for help in writing the paper.

\section{CONTRIBUTION OF AUTHORS}

Research concept-Dr. Mahendra Singh, Dr. Swetlana Sachan

\section{Research design- Dr. Swetlana Sachan}

Supervision- Dr. Mahendra Singh

Materials- Dr. Anita Omhare, Dr. Neelima Verma

Data collection- Dr. Swetlana Sachan

Data analysis- Dr. Swetlana Sachan

Literature search- Dr. Swetlana Sachan

Writing article- Dr. Swetlana Sachan

Critical review- Dr. Mahendra Singh

Article editing- Dr. Swetlana Sachan, Dr. Anveksha

Final approval- Dr. Mahendra Singh, Dr. Swetlana Sachan

\section{REFERENCES}

[1] Inwald EC, Klinkhammer-Schalke M, Hofstadter F, Zeman F, Koller $\mathrm{M}$, et al. Ki-67 is a prognostic parameter in breast cancer patients: results of a large population-based cohort of a cancer registry. Breast Cancer Res. Treat., 2013; 139(2): 539-52.

[2] Agarwal G, Ramakant P. Breast Cancer Care in India: The Current Scenario and the Challenges for the Future. Breast Care Basel., 2008; 3(1): 21-27.

[3] Allred DC, Mohsin SK, Fuqua SA. Histological and biological evaluation human premalignant breast disease. Endocr. Relat. Cancer, 2001; 8(1): 47-61.

[4] Sun YS, Zhao Z, Yang ZN, Xu F, Lu HJ, et al. Risk Factors and Preventions of Breast Cancer. Int. J. Biol Sci., 2017; 13(11): 1387-97.

[5] Azambuja DE, Cardoso F, De Castro G, Colozza M, Mano MS, et al. Ki-67 as prognostic marker in early breast cancer: A meta-analysis of published studies involving 12,155 patients. Br. J. Cancer, 2007; 2196(10): 1504-13.

[6] Tan PH, Bay BH, Yip G, Selvarajan S, Tan P, et al. Immunohistochemical detection of $\mathrm{Ki67}$ in breast cancer correlates with transcriptional regulation of genes related to apoptosis and cell death. Mod. Pathol., 2005; 18(3): 374-81.

[7] Li FY, Wu SG, Zhou J, Sun JY, Lin Q, et al. Prognostic value of Ki-67 in breast cancer patients with positive axillary lymph nodes: a retrospective cohort study. PLoS One, 2014; 39(2): 872-964.

[8] Rosai J. Breast. In: Rosai and Ackerman's Surgical Pathol. $9^{\text {th }}$ ed. Noida: Reed Elsevier India Private Limited, 2009; pp. 1787-27.

[9] Pandey ST, Malik R, Trichal VK, Nigam RK. Breast Cancer: Correlation of Molecular Classification with Clinicohistopathology. Sch. J. App. Med. Sci., 2015; 3(2G): 1018-26.

[10]Nabi M, Ahangar A, Kaneez S. Estrogen Receptors, Progesterone Receptors and their Correlation with respect to HER-2neu Status, Histological Grade, Size of Lesion, Lymph node Metastasis, Lymphovascular, Involvement and Age in Breast Cancer patients in a hospital in north India. Asian J. Med. Sci., 2016; 7(3): 28-34.

[11]Nggada HA, Yawe KD, Abdulazeez J, Khalil MA. Breast cancer burden in Maiduguri, North eastern Nigeria. Breast J., 2008; 14(3): 284-86.

[12]Shet T, Agrawal A, Nadkarni M, Palkar M, Havaldar R, et al. Hormone receptors over the last 8 years in a cancer referral center in India: what was what is?. Ind. J. Pathol. Microbiol., 2009; 52 (2): 171-74. 
[13]Godwin A, Gabriel U, Noli AN, Bassey I, Victor J, et al. Histological Type and Tumour Grade in Nigerian Breast Cancer: Relationship to Menarche, Family History of Breast Cancer, Parity, Age at First Birth, and Age at Menopause. IOSR J. Dental Med. Sci., 2013; 7(5): 58-63.

[14]Yip Ch, BP N, Daniel J, Foo Y, Mohamed A, et al. Roles of Ki67 in Breast Cancer Important for Management? Asian Pac J. Cancer Prev., 2016; 17(3): 1077-82.

[15]Surakasula A, Nagarjunapu GC, Raghavaiah KV. A comparative study of pre- and post-menopausal breast cancer: Risk factors, presentation, characteristics management. J. Res. Pharm, Pract., 2014; 3(1): 12-18.

[16]Sebastiani F, Cortesi L, Sant M, Lucarini V, Cirilli C, et al. Increased Incidence of Breast Cancer in Postmenopausal Women with High Body Mass Index at the Modena Screening Program. J. Breast Cancer, 2016; 19(3): 283-91.

[17]Hall IJ, Moorman PG, Millikan RC, Newman B. Comparative analysis of breast cancer risk factors among African-American women and White women. Am. J. Epidemiol., 2005; 161(1): 40-51.

[18]Ayad E, Soliman A, Anis SE, Salem AB, Hu P, et al. Ki 67 assessment in breast cancer in an Egyptian population: a comparative study between manual assessments on optical microscopy digital quantitative assessment. Diagn. Pathol., 2018; 13(1): 63.

[19]Soliman NA, Yussif SM. Ki-67 as a prognostic marker according to breast cancer molecular subtype. Cancer Biol. Med., 2016; (4): 496-04.

[20]Rakha EA, Reis-Filho JS, Baehner F, Dabbs DJ, Decker $\mathrm{T}$, et al. Breast cancer prognostic classification in the molecular era: the role of histological grade. Breast Cancer Res., 2010; 12(4): 207.
[21]Pierga JY, Leroyer A, ViehI P, Mosseri V, Chevillard S, et al. Long term prognostic value of growth fraction determination by Ki-67 immunostaining in primary operable breast cancer. Breast Cancer Res. Treat., 1996; 37(1): 57-64.

[22]Aman NA, Doukoure B, Koffi KD, Koui BS, Traore ZC, et al. Immunohistochemical Evaluation of $\mathrm{Ki}-67$ and Comparison with Clinicopathologic Factors in Breast Carcinomas. Asian Pac. J. Cancer Prev., 2019; 20(1): 73-79.

[23]Pinto $A E$, André $S$, Pereira T, Nóbrega $S$, Soares J. Prognostic comparative study of S-phase fraction and Ki-67 index in breast carcinoma. J. Clin. Pathol., 2001; 54(7): 543-49.

[24]Cheang MC, Chia SK, Voduc D, Gao D, Leung S, et al. Ki67 index, HER2 status, and prognosis of patients with luminal B breast cancer. J. Natl. Cancer Inst., 2009; 101(10): 736-50.

[25]Ambroise M, Ghosh M, Mallikarjuna VS, Kurian A. Immunohistochemical profile of breast cancer patients at a tertiary care hospital in South India. Asian Pac. J. Cancer Prev., 2011; 12(3): 625-29.

[26]Ragab HM, Samy N, Afify M, El Maksoud NA, Shaaban HM. Assessment of Ki-67 as a potential biomarker in patients with breast cancer. J. Genet. Eng. Biotechnol., 2018; 16(2): 479-84.

[27]Madani SH, Payandeh M, Sadeghi M, Motamed H, Sadeghi $\mathrm{E}$. The correlation between $\mathrm{Ki}-67$ with other prognostic factors in breast cancer: A study in Iranian patients. Ind. J. Med. Paediatr. Oncol., 2016; 7(2): 9599.

[28]Jain R, Malik R, Trichal VK, Jain A, Bakna M. Immunohistochemical expression of Ki-67 in invasive breast carcinoma and its correlation with prognostic parameters. Int. J. Med Res. Review, 2016; 4(5): 76570. 